\title{
External Ear Canal Adenoid Cystic Carcinoma
}

\author{
Dış Kulak Yolu Adenoid Kistik Karsinomu
}

\section{Adam Mohamad ${ }^{1,2}$, Irfan Mohamad ${ }^{1}$, Rohaida Ibrahim², Wong Kim Yew Richard², Wan Emelda Wan Mohamad²} Anura Aman², Suhaila Abdullah ${ }^{3}$

\footnotetext{
${ }^{1}$ Department of Otorhinolaryngology-Head \& Neck Surgery, School of Medical Sciences, Universiti Sains Malaysia Health Campus, Kota Bharu, Kelantan, Malaysia

${ }^{2}$ Department of Otorhinolaryngology, Hospital Tengku Ampuan Afzan, Kuantan, Pahang, Malaysia

${ }^{3}$ Department of Pathology, Hospital Tengku Ampuan Afzan, Kuantan, Pahang, Malaysia
}

\begin{abstract}
Primary malignancy involving the external auditory canal is rare, with $80 \%$ of them being squamous cell carcinoma while $5 \%$ of them are adenoid cystic carcinoma. These tumours are known for its high rates of recurrence, significant morbidities from surgical management and adjuvant radiotherapy, as well as eventual death of the patient. We describe a case of an elderly female with right ear canal mass who presented with recurrent right ear pain. After the tumour was excised, it was confirmed to be adenoid cystic carcinoma. This case highlights the rarity of the entity of adenoid cystic carcinomas involving the external auditory canal; and how its subtle initial presentation can be mistaken to be a clinically benign condition.
\end{abstract}

Key Words: Adenoid cystic carcinoma, external auditory canal, radiotherapy

Received: 06.08.2018

Accepted:08.13.2018

\section{ÖZET}

Dış kulak yolunu içeren primer malignite nadirdir, bunların \% 80'inde skuamöz hücreli karsinom,\% 5 'inde adenoid kistik karsinom vardır. Bu tümörler yüksek nüks oranları, cerrahi tedavi ve adjuvan radyoterapiden kaynaklanan önemli morbiditeler ve ayrıca hastanın ölümüyle bilinirler. Yineleyen sağ kulak ağrısı ile başvuran sağ kulak kanal kitlesi olan yașlı bir kadın olgusunu sunuyoruz. Tümör eksize edildikten sonra adenoid kistik karsinom olduğu doğrulandı. Bu vaka, dış kulak yolunu içeren adenoid kistik karsinomların varlığııın nadir olduğunu göstermektedir ve gizli başlangıcı klinik olarak iyi huylu bir durum olarak yanlış anlaşılabilir.

Anahtar Sözcükler: Adenoid kistik karsinomu, dı̧̧ kulak yolu, radyoterapi

Geliş Tarihi: 08.06.2018

Kabul Tarihi:13.08.2018

\section{INTRODUCTION}

Adenoid cystic carcinoma (ACC) is a high grade malignancy which is associated with poor outcome. It is a rare epithelial tumour which comprises of about $1 \%$ of all malignant tumours involving the oral and maxillofacial region(1). Billroth in 1859 is the first one who described ACC as "cylindroma", which is commonly associated with salivary gland tumour, though it may also arise from any site where mucous gland exists. Half of these tumours occur in glandular areas other than the major salivary glands; such as the hard palate. It can also arise from the minor salivary glands(2). Rare locations include the nasopharynx, lacrimal gland, breast, vulva, oesophagus, cervix and Cowper's gland of the male reproductive system. Involvement of external auditory (EAC) canal is extremely rare.

\section{CASE REPORT}

A 50-year-old Malay lady, with underlying diabetes mellitus, hypertension and hyperlipidaemiacomplained of a 9-month history of recurrent right ear pain prior to her presentation. She was initially treated as right ear furunculosis. However, after a few courses of antibiotics, the ear pain did not resolve. On examination, there was a swelling at the anterosuperior part of the right ear canal, which was firm and mildly tender on manipulation. It was neither associated with hearing loss nor tinnitus over the right ear. High resolution computed tomography (HRCT) temporal was done which revealed a small soft tissue density lesion arising from the anterosuperior wall of the cartilaginous portion of the right ear canal (Figure 1) which was suggestive of a benign lesion with the possibility of ceruminoma.

Address for Correspondence / Yazışma Adresi: Adam Mohamad, MD Department of Otorhinolaryngology-Head \& Neck Surgery, School of Medical Sciences, Universit Sains Malaysia Health Campus, 16150 Kota Bharu, Kelantan, Malaysia \& Department of Otorhinolaryngology, Hospital Tengku Ampuan Afzan, 25100 Kuantan, Pahang, Malaysia. E-mail:persona522115@gmail.com

CTelif Hakkı 2018 Gazi Üniversitesi Tıp Fakültesi - Makale metnine http://medicaljournal.gazi.edu.tr/ web adresinden ulaşılabilir. (C) Copyright 2018 by Gazi University Medical Faculty - Available on-line at web site http://medicaljournal.gazi.edu.tr/

doi:http://dx.doi.org/10.12996/gmj.2018.101 
Excision of the mass was done via an end-aural approach (Figure 2). Histopathological examination (HPE) showed a fragment of tumour tissue composed of variety of tubular and cribriform structures as solid infiltrative trabecular pattern (predominant). The malignant cells are mild to moderately pleomorphic, having small angulated, hyperchromatic and vesicular nuclei. The cribriform pattern shows sharply defined round spaces filled light basophilic myxoid ground substance or hyalinised material. The malignant tumours are surrounded by dense fibro-hyalinized stroma.
Abnormal mitoses are seen. In view of these findings, it was reported as adenoid cystic carcinoma (Figure 3). However, there is no information regarding the margin on the HPE report.

A repeat HRCT scan of the temporal bone and computed tomography (CT) of neck regions were done for surveillance, which revealed no abnormality. The current staging of her tumour was $\mathrm{T}_{1} \mathrm{~N}_{0} \mathrm{M}_{0}$. She was referred to the Oncologist for further treatment. She was offered either revision surgery (lateral temporal bone resection) or radiotherapy; however, she was not keen for either forms of treatment due to logistical reasons. She was given monthly follow-up at our clinic.

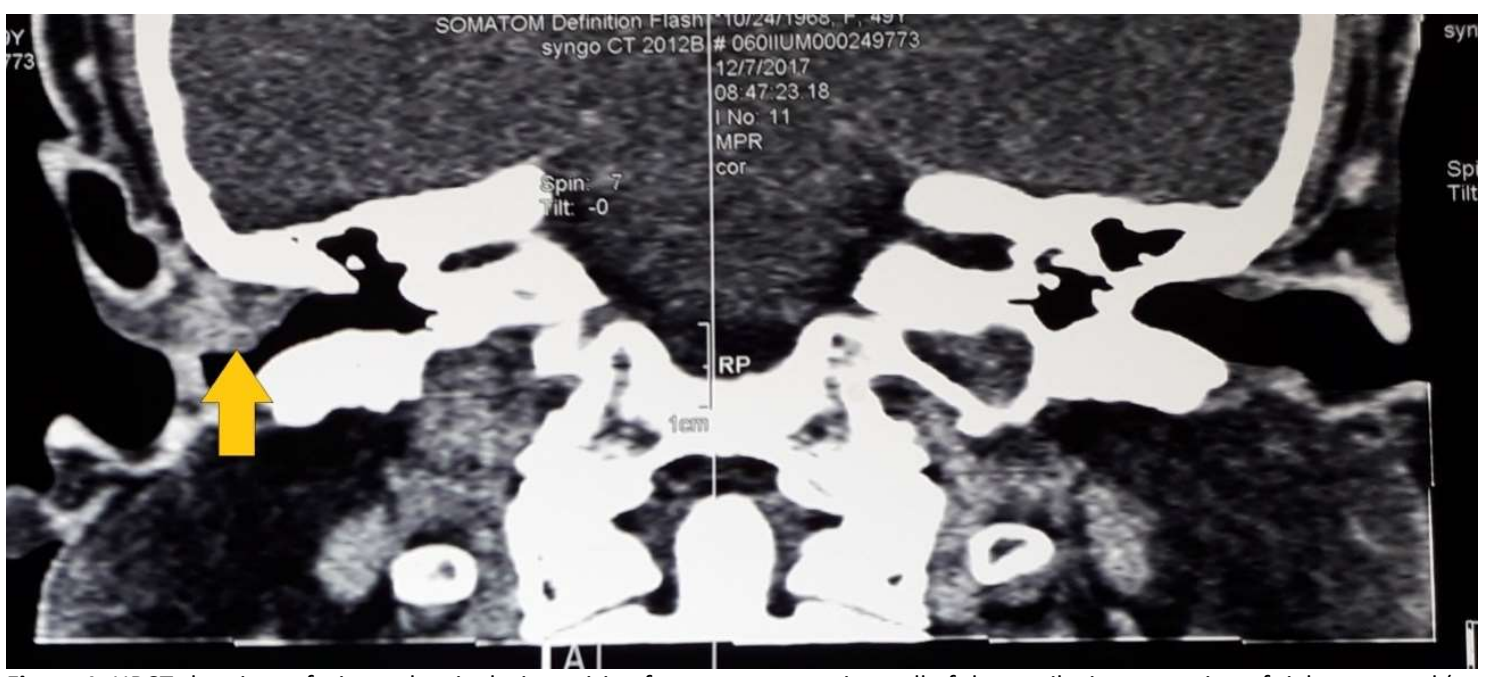

Figure 1: HRCT showing soft tissue density lesion arising from anterosuperior wall of the cartilaginous portion of right ear canal (arrow)

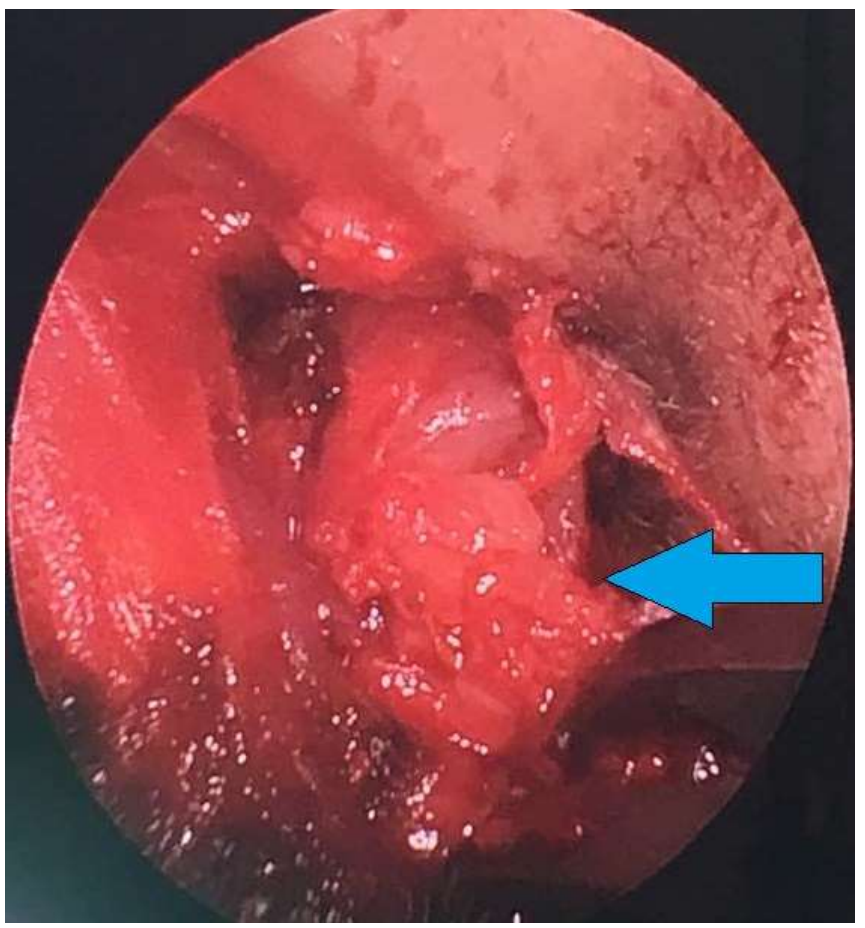

Figure 2: Mass (arrow), during the excision biopsy procedure

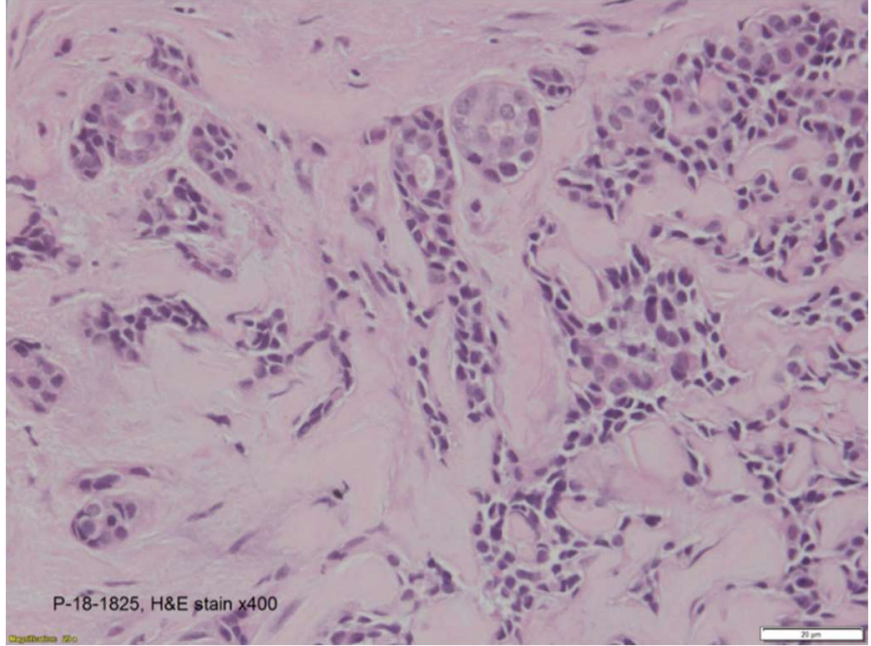

Figure 3: Adenoid cystic carcinoma surrounded by dense fibrohyalinized stroma, and the malignant cells are mild to moderately pleomorphic, having small angulated, hyperchromatic and vesicular nuclei (H\&E stain, X400 magnification).

\section{DISCUSSION}

Malignant tumours involving the EAC are rare. When present, the most common histological subtype is squamous cell carcinoma. ACC arising from EAC is even rarer. ACC is usually more common in the salivary glands of head and neck region and in some cases, the tumour arises from the adjacent parotid gland and extends into the ear canal via the notch of Santorini(3). In our case, the parotid was not involved based on clinical examination and radiological findings. It was proposed that primary ACC in the EAC arises from ceruminous glands. This is based on similar histologic features found on microscopic studies of these tumours and ceruminous glands(4). 
The tumour are known for the tendency of local recurrence as well as perineural invasion (5). The incidence of perineural involvement were estimated to be $68 \%$ and $88 \%$ respectively $(6,7)$. ACC occurs predominantly among women between the $5^{\text {th }}$ and $6^{\text {th }}$ decade of life(8).

Ceruminous gland tumours can be classified into ceruminous adenoma, pleomorphic adenoma, cerumonious adenocarcinoma and ACC. In fact, our patient was initially diagnosed clinically as ceruminoma given the clinical appearance of the mass and absence of bony erosion in the CT scan which resembling benign condition.

ACC has 3 main histological patterns which are tubular, cribriform and solid(7) . In our patient, the tumour contains tubular and cribriform patterns. The characteristic feature of ACC is the presence of sharp pain radiating away from the ear and the findings of a lesion at the EAC. The EAC lesion may present as a polyp, ulceration or granulation tissue. In advanced cases, the patient may already have facial paresis and tinnitus due to spread of the disease into parotid gland invading the perineural of facial nerve or the inner ear respectively. In term of radiological investigation, HRCT and magnetic resonance imaging are the imaging of choice. ACC may locally invade soft tissue and bone, extend into the parotid gland and temporomandibular joint as well as metastasize to regional lymph nodes, lung and liver(9). However, it is more common that a primary ACC in the parotid gland extends into the EAC. In our case CT staging shows no evidence of extension and metastasis.

Treatment of EAC ACC consists of at least lateral temporal bone resection along with superficial parotidectomy. However, due to the possibility of nodal metastasis based on CT scan, a neck dissection is advised(7). Post-operative radiotherapy is recommended for all patients due to the high prevalence of perineural invasion and limited margin in cases of $\operatorname{ACC}(7,10)$. In our case, unfortunately the patient refused all the treatment modalities offered

\section{CONCLUSION}

ACC of the EAC is a rare malignant tumour with a highly aggressive behaviour. Because of that, radical surgery and post-operative radiotherapy is needed to minimise the risk of recurrence. Clinicians should have a higher index of suspicion of ACC in an EAC lesion, especially among elderly female in their fifth to sixth decades of life who presents with recurrent ear pain and swelling which are unresponsive to antibiotics.

\section{Conflict of interest}

No conflict of interest was declared by the authors.

\section{REFERENCES}

1.Kokemueller $\mathrm{H}$, Eckardt A, Brachvogel $\mathrm{P}$ et al. Adenoid cystic carcinoma of the head and neck - a 20 years experience. International Journal of Oral and Maxillofacial Surgery. 2004;33:25-31.

2.Berdal $P$, Besche Ad, Mylius E. Cylindroma of salivary glands a report of 80 cases. Acta Oto-Laryngologica. 1970;69:170-3.

3.Szanto PA, Luna MA, Tortoledo ME et al. Histologic grading of adenoid cystic carcinoma of the salivary glands. Cancer. 1984;54:1062-9.

4.Zainor S, Mamat H, Saad SM et al. Adenoid cystic carcinoma of external auditory canal: A case report. Egyptian Journal of Ear, Nose, Throat and Allied Sciences. 2013;14:41-4.

5.Spiro RH. Salivary neoplasms: Overview of a 35-year experience with 2,807 patients. Head \& Neck. 1986;8:177-84.

6.Perzin $\mathrm{KH}$, Gullane P, Conley J. Adenoid cystic carcinoma involving the external auditory canal a clinicopathologic study of 16 cases. Cancer. 1982;50:2873-83.

7.Dong F, Gidley PW, Ho T et al. Adenoid cystic carcinoma of the external auditory canal. The Laryngoscope. 2008;118:1591-6.

8.Waldron CA, El-Mofty SK, Gnepp DR. Tumors of the intraoral minor salivary glands: a demographic and histologic study of 426 cases. Oral Surgery, Oral Medicine, Oral Pathology. 1988;66:323-33.

9.Bhatt MC. A rare case of adenoid cystic carcinoma of ceruminous gland of EAC. Otolaryngology Online Journal.2016;6:101.

10.Silverman DA, Carlson TP, Khuntia D et al. Role for postoperative radiation therapy in adenoid cystic carcinoma of the head and neck. The Laryngoscope. 2004;114:1194-9. 